\title{
EXTENDED COMPLICATIONS OF URETHROPLASTY
}

\author{
HOSAM S. AL-QUDAH, RICHARD A. SANTUCCI \\ Departments of Urology, Detroit Receiving Hospital and Wayne State University School of Medicine, \\ Detroit, Michigan, USA
}

\begin{abstract}
Introduction: An extensive study of complications following urethroplasty has never been published. We present 60 urethroplasty patients who were specifically questioned to determine every possible early and late complication.

Materials and Methods: Retrospective chart review of urethroplasty patients between August 2000 and March 2004. An "open format" questioning style allowed maximal patient reporting of all complications, no matter how minor.

Results: 60 patients underwent 62 urethroplasties ( 24 anterior anastomotic, 19 buccal mucosal and 10 fasciocutaneous, 9 posterior anastomotic) with mean follow-up of 29 months. Early complications occurred in $40 \%$, but only $3 \%$ were major (rectal injury and urosepsis). Early minor complications included scrotal swelling, scrotal ecchymosis and urinary urgency. Late complications occurred in $48 \%$, but only $18 \%$ were significant (erectile dysfunction, chordee and fistula). Late minor complications included a feeling of wound tightness, scrotal numbness and urine spraying. Fasciocutaneous urethroplasty caused the most significant complications, and buccal mucus urethroplasty the least, while also resulting in the lowest recurrence rate $(0 \%)$.

Conclusions: Serious complications after urethroplasty (3\% early and 18\% late) appear similar to those reported elsewhere, but minor bothersome complications appear to occur in much higher numbers than previously published (39\% early and $40 \%$ late). While all the early complications were resolved and most (97\%) were minor, less than half of the late complications were resolved, although most $(82 \%)$ were minor. These complication rates should be considered when counseling urethroplasty patients, and generally tend to support the use of buccal mucosal onlay urethroplasty as it had the lowest rate of serious side effects.
\end{abstract}

Key words: urethra; urethral stricture; surgery; complications

Int Braz J Urol. 2005; 31: 315-25

\section{INTRODUCTION}

Urethroplasty has excellent success rates against urethral stricture (1-5), that far exceed that seen with direct visual internal urethrotomy (DVIU) and dilation $(6,7)$. The total impact of urethroplasty on the patient is unknown as an extensive study of complications after urethroplasty has not yet been published. We present our experience with 60 ure- throplasty patients especially questioned so as to determine every possible early and late complication.

\section{MATERIALS AND METHODS}

A retrospective chart review of 60 consecutive patient who underwent 62 urethroplasty operations between August 2000 and March 2004, including 24 anterior anastomotic, 19 ventral onlay buccal 
mucosal graft, 10 fasciocutaneous onlay flap, and 9 posterior anastomotic urethroplasties. In 2 patients, multiple simultaneous procedures were performed: 1 patient had a proximal buccal graft plus distal fasciocutaneous flap, another had a proximal anastomotic plus distal fasciocutaneous flap. The patient mean age was 46 years (18 to 78 years) with a mean follow-up of 29 months (10 to 53 months).

Patients' records were reviewed regarding stricture cause, stricture length determined by retrograde urethrogram (RUG), location, type of urethroplasty, early complications, results of postoperative urethrogram, postoperative flow rates, late complications and stricture recurrence. Strictures ranged from 0.5 to $11 \mathrm{~cm}$ in length (mean $2.8 \mathrm{~cm}$ ) and etiology, location, and treatments varied (Table-1). All spontaneous complaints were meticulously recorded. Further "open format" questioning allowed maximum

Table 1 - Etiology of urethral strictures, location and type of urethroplasty, overall early and late complications in 60 patients with 62 urethral strictures.

\begin{tabular}{lrr}
\hline Etiology of Stricture & N & $(\boldsymbol{\%})$ \\
Balanitis xerotica obliterans & 1 & $(2)$ \\
Congenital & 1 & $(2)$ \\
GU instrumentation & 10 & $(17)$ \\
Inflammatory & 11 & $(18)$ \\
Trauma & 16 & $(27)$ \\
Unknown & 21 & $(35)$ \\
Total & 60 & $(100)$ \\
& & \\
Location of Stricture & $\mathbf{N}$ & $(\boldsymbol{\%})$ \\
& & \\
Prostato-membranous & 1 & $(2)$ \\
Membrano-bulbar & 8 & $(13)$ \\
Penile & 12 & $(19)$ \\
Bulbar & 41 & $(66)$ \\
Total & $62(100)$ \\
& & \\
Type of Urethroplasty & $\mathbf{N}$ & $(\boldsymbol{\%})$ \\
& & \\
Anastomotic & 24 & $(39)$ \\
Buccal mucosal onlay & 19 & $(31)$ \\
Fasciocutaneous & 10 & $(16)$ \\
Posterior & 9 & $(15)$ \\
Total & $62(100)$ \\
\hline
\end{tabular}

patient reporting of all complications, no matter how minor. Each patient was asked, "Is there anything at all bothering you after surgery?" Later, they were prompted with "Is there anything else you can think of?" Finally, they were specifically prompted for complaints concerning voiding, sexual function, wound problems, and mouth problems (after buccal graft harvest).

All patients were operated on by the same surgeon (RAS). All patients received perioperative antibiotics and were free of urinary tract infection on the day of surgery. Standard techniques for urethroplasty were followed, including meticulous tissue handling, watertight closure, loop magnification and careful high lithotomy positioning.

\section{RESULTS}

Overall, early complications occurred after $40 \%$ of operations and late complications occurred after $48 \%$. Early complications were major in only $3 \%$ of cases (rectal injury and urosepsis). The majority of early complications were minor (scrotal swelling, scrotal ecchymosis and urinary urgency) and all resolved.

Not including stricture recurrence, late complications were major in $18 \%$ of cases (erectile dysfunction - ED, chordee and fistula). Only 9/25 (36\%) of the patients with minor late complications (feeling of wound tightness, scrotal numbness and urine spraying) resolved spontaneously or with medication. Stricture recurrence occurred after $10 \%$ of operations.

Among patients with anterior anastomotic urethroplasty, 25\% and 54\% had early and late complications respectively (Table-2). None of the patients had early major complications and 5/24 (20\%) of them had late major complications. For patients with posterior urethroplasty, $56 \%$ (early) and $44 \%$ (late) had complications, and 2/9 (22\%) patients had late major complications (Table-3). For buccal mucosal onlay patients, 37\% had early and late complications. 1/19 $(5 \%)$ of the early and $0 / 19(0 \%)$ of the late patients had serious complications (Table-4). Fasciocutaneous urethroplasty patients had $60 \%$ early and late complications. $1 / 10(10 \%)$ and $4 / 10(40 \%)$ of the patients had serious early and late complications respectively (Table-5). 
Table 2 - Anterior anastomotic urethroplasty complications, $n=24$.

\begin{tabular}{|c|c|c|c|}
\hline Early Complications & $\mathbf{N}(\%)$ & Late Complications & $\mathbf{N}(\%)$ \\
\hline Minor Complications & & Minor Complications & \\
\hline Failure to void & $1 \quad(4)$ & Perineal hypoesthesia & 1 (4) \\
\hline Retrograde urethrography leak & $1 \quad(4)$ & Post void leak & $4(17)$ \\
\hline Mild scrotal tenderness & 1 (4) & UTI & 1 (4) \\
\hline Foley fall out & $1 \quad(4)$ & Penile pain & 1 (4) \\
\hline Scrotal ecchymosis & 1 (4) & Scrotal pain & 1 (4) \\
\hline Urgency (self limiting) & $1 \quad(4)$ & Scrotal scar & 1 (4) \\
\hline All & $6(25)$ & Wound discomfort & 1 (4) \\
\hline \multirow[t]{4}{*}{ None } & $18(75)$ & Irritative LUTS & 1 (4) \\
\hline & & Stream spraying & 1 (4) \\
\hline & & Ejaculatory dysfunction & 1 (4) \\
\hline & & All & $10(42)$ \\
\hline Major Complications & & Major Complications & \\
\hline \multirow[t]{4}{*}{ None } & $24(100)$ & Chordee & 1 (4) \\
\hline & & Erectile dysfunction (Viagra responsive) & $4(17)$ \\
\hline & & All * & $5(21)$ \\
\hline & & Recurrence & $2(8)$ \\
\hline
\end{tabular}

* 2 patients had both minor and major complications

Table 3 - Posterior anastomotic urethroplasty complications, $n=9$.

\begin{tabular}{llll}
\hline Early Complications & N $(\%)$ & Late Complications & N (\%) \\
\hline Minor Complications & & Minor Complications & $1(11)$ \\
Failure to void & $1(11)$ & Scrotal pain & $1(11)$ \\
Retrograde urethrography leak & $1(11)$ & Post void leak & $2(22)$ \\
Scrotal swelling & $1(11)$ & All & \\
Scrotal ecchymosis & $2(22)$ & & $1(11)$ \\
Epididymitis & $1(11)$ & & $1(11)$ \\
Urgency & $1(11)$ & & $2(22)$ \\
All & $5(56)$ & & \\
None & $4(44)$ & Major Complications & $(0)$ \\
Major Complications & & Chordee & \\
None & $9(100)$ & Erectile dysfunction & \\
& & All & \\
\end{tabular}


Table 4 - Buccal mucosal onlay urethroplasty complications, $n=19$.

\begin{tabular}{|c|c|c|c|c|}
\hline Early complications & $\mathbf{N}(\%)$ & Late Complications & $\mathbf{N}$ & $(\%)$ \\
\hline Minor Complications & & Minor Complications & & \\
\hline Hematuria & $1(5)$ & Hand numbness & 1 & (5) \\
\hline Retrograde urethrography leak & $3(16)$ & Perineal hypoesthesia & 1 & (5) \\
\hline Scrotal hematoma & $1 \quad(5)$ & Post void leak & 2 & (5) \\
\hline Small wound dehiscence & $1(5)$ & Scrotal hyperesthesia & 1 & (5) \\
\hline Wound tightness & $1(5)$ & Stensen's duct squirting & & \\
\hline \multirow[t]{3}{*}{ All } & $7(37)$ & Saliva out of mouth when eating & 1 & $(5)$ \\
\hline & & UTI & 1 & $(5)$ \\
\hline & & All & 7 & (37) \\
\hline Major Complications & & Major Complications & & \\
\hline \multirow[t]{2}{*}{ Urosepsis } & $1 \quad(5)$ & None & 19 & $(100)$ \\
\hline & & Recurrence & 0 & $(0)$ \\
\hline
\end{tabular}

\section{COMMENTS}

Early and late effects of urethroplasty, including complications, have not been extensively reported in the literature. They are usually discussed as part of broader reports of operative outcomes that generally concentrate on rates of surgical success, and only discuss the most easily recognized complications such as erectile dysfunction and incontinence. Compared to these other studies, our data indicate a high degree

Table 5 - Fasciocutaneous urethroplasty complications, $n=10$.

\begin{tabular}{llll}
\hline Early Complications & $\mathbf{N}(\boldsymbol{\%})$ & Late Complications & $\mathbf{N}(\boldsymbol{\%})$ \\
\hline Minor Complications & & Minor Complications \\
Epididymitis & $1(10)$ & Penile pain & $1(10)$ \\
Foley fall out (replaced) & $1(10)$ & Penile shortening & $1(10)$ \\
Penile ecchymosis & $1(10)$ & Post void leak & $5(50)$ \\
Penile swelling & $1(10)$ & Stress incontinence & $1(10)$ \\
Penile skin necrosis & $1(10)$ & Urine spraying & $1(10)$ \\
UTI & $1(10)$ & All & $6(60)$ \\
Retrograde urethrography leak & $2(20)$ & & \\
All & $6(60)$ & & \\
& & Major Complications \\
Major Complications & $1(10)$ & Chordee & $2(20)$ \\
Rectal injury & $1(10)$ & Temporary fistula & $2(20)$ \\
All & & All * & $4(40)$ \\
& & Recurrence & $4(40)$ \\
\hline
\end{tabular}

* 4 patients had recurrence and late complications 
Table 6 - Comparing complications after anterior anastomotic urethroplasty in this study to 168 patients reported at the University of California San Francisco, Santucci et al. (ref. 2).

\begin{tabular}{lcc}
\hline Complication & $\begin{array}{c}\text { Santucci } \\
\text { et al. (\%) }\end{array}$ & $\begin{array}{c}\text { Present } \\
\text { Study (\%) }\end{array}$ \\
\hline Thigh numbness & 2 & 0 \\
Small wound dehiscence & 1 & 0 \\
Scrotal hematoma & $<1$ & 0 \\
Erectile dysfunction & $<1$ & 17 \\
Catheter dislodgment & $<1$ & 9 \\
Wound infection & $<1$ & 0 \\
\hline
\end{tabular}

of patient complaints, likely because our method of inquiry encouraged the voicing of all possible concerns, and, in this method, some minor issues that would not be considered true "complications" are reported. When other centers determined complication rates by direct inquiry, the reported rates of complications also increased. In a report of ED after anterior anastomotic urethroplasty from a single center determined first by chart review, (2) then later by patient questionnaire, (8) ED rates rose from $<1 \%$ to $27 \%$.
Overall, $40 \%$ of our patients had early complications and $48 \%$ had late complications. The complication rate differed by urethroplasty type, as has been previously reported $(9,10)$. For example, in our series the rate of serious complications after anterior anastomotic urethroplasty was $21 \%$, while that for fasciocutaneous onlay urethroplasty was $40 \%$. This corresponds to results already published. Andrich et al. (11) reported a significantly higher rate of complications after fasciocutaneous urethroplasty (33\%) compared to anastomotic urethroplasty $(7 \%)$.

Table 7 - Comparing complications after fasciocutaneous urethroplasty in this study to 84 patients reported at the Institute of Urology in London, Andrich et al. (ref. 11).

\begin{tabular}{lcc}
\hline Complication & $\begin{array}{c}\text { Andrich } \\
\text { et al. (\%) }\end{array}$ & $\begin{array}{c}\text { Present } \\
\text { Study (\%) }\end{array}$ \\
\hline Erectile dysfunction & 2 & 0 \\
Post-void dribbling & 28 & 50 \\
Diverticulum & 12 & 0 \\
UTI & 5 & 0 \\
Fistula & 3 & 20 \\
Chordee & 3 & 20 \\
Recurrence & 21 (at 5 years) & 40 \\
\hline
\end{tabular}

Table 8 - Reported complications after anterior anastomotic urethroplasty.

\begin{tabular}{|c|c|c|c|c|c|c|}
\hline Reference & $\mathbf{N}$ & $\begin{array}{l}\text { Mean Follow-up } \\
\quad \text { (months) }\end{array}$ & $\begin{array}{c}\text { Early } \\
\text { Complications (\%) }\end{array}$ & $\begin{array}{c}\text { Late } \\
\text { Complications (\%) }\end{array}$ & $\begin{array}{l}\text { Recurrence } \\
\text { Rate }(\%)\end{array}$ & $\begin{array}{c}\text { All Complications } \\
(\%)\end{array}$ \\
\hline $\begin{array}{l}\text { Lindell } \\
\text { et al. } \\
\text { (1993), ref. } 14\end{array}$ & 49 & 48 & - & 10 & 4 & - \\
\hline $\begin{array}{l}\text { Schlossberg } \\
(2000) \text {, ref. } 15\end{array}$ & 130 & 45 & - & - & 2 & 8 \\
\hline $\begin{array}{l}\text { Santucci } \\
\text { et al. } \\
\text { (2002), ref. } 2\end{array}$ & 168 & 70 & 6 & - & 5 & - \\
\hline Current study & 24 & 26 & 25 & 54 & 8 & - \\
\hline
\end{tabular}


Table 9 - Reported complications after posterior urethroplasty (for posterior urethral distraction defects).

\begin{tabular}{lcccccc}
\hline Reference & N & Approach & $\begin{array}{c}\text { Mean Follow-up } \\
\text { (Months) }\end{array}$ & $\begin{array}{c}\text { Early } \\
\text { Complications (\%) }\end{array}$ & $\begin{array}{c}\text { Late } \\
\text { Complications (\%) }\end{array}$ & $\begin{array}{c}\text { Recurrence } \\
\text { Rate (\%) }\end{array}$ \\
\hline $\begin{array}{l}\text { Mundy } \\
\text { (1996), ref. 16 }\end{array}$ & 82 & Perineal* $^{*}$ & 60 & Urgency 66 & Impotence 7** & 12 \\
& & & $\begin{array}{c}\text { Stress } \\
\text { Incontinence 37 }\end{array}$ & & \\
& & & Impotence 26 & & 11 \\
$\begin{array}{l}\text { Morey \& } \\
\text { (1997), ref. 17 }\end{array}$ & 52 & $\begin{array}{c}\text { Perineal and } \\
\text { transpubic }\end{array}$ & $>12$ months & - & - & 5 \\
$\begin{array}{l}\text { Flynn } \\
\text { (2003), ref. 1 }\end{array}$ & 109 & Perineal * & 64 & & & \\
Current study & 9 & Perineal & 26 & 56 & 44 & 0 \\
\hline
\end{tabular}

* Procedures including inferior pubectomy and supra-corporal re-routing of urethra. ** Permanent erectile dysfunction.

Table 10 - Reported complications after buccal mucosal onlay urethroplasty.

\begin{tabular}{|c|c|c|c|c|c|c|}
\hline Reference & $\mathbf{N}$ & Approach & $\begin{array}{l}\text { Mean Follow-up } \\
\text { (Months) }\end{array}$ & $\begin{array}{c}\text { Early } \\
\text { Complications (\%) }\end{array}$ & $\begin{array}{c}\text { Late } \\
\text { Complications (\%) }\end{array}$ & $\begin{array}{c}\text { Recurrence } \\
\text { Rate }(\%)\end{array}$ \\
\hline $\begin{array}{l}\text { Kellner et al. } \\
\text { (2004), ref. } 18\end{array}$ & 23 & Ventral & 50 & 9 & & 13 \\
\hline $\begin{array}{l}\text { Kane et al. } \\
\text { (2002), ref. } 19\end{array}$ & 53 & Ventral & 25 & 6 & & 6 \\
\hline $\begin{array}{l}\text { Pansadoro et al. } \\
\text { (2003), ref. } 4\end{array}$ & 65 & $\begin{array}{l}\text { Ventral } \\
\text { and dorsal }\end{array}$ & 41 & 6 & 8 & 3 \\
\hline $\begin{array}{l}\text { Elliott et al. } \\
\text { (2003), ref. } 3\end{array}$ & 60 & Ventral & 47 & 0 & & 10 \\
\hline $\begin{array}{l}\text { Andrich et al. } \\
\text { (2001), ref. } 5\end{array}$ & 29 & Ventral & 60 & & 21 & 14 \\
\hline $\begin{array}{l}\text { Andrich et al. } \\
\text { (2001), ref. } 5\end{array}$ & 42 & Dorsal & 60 & & 17 & 5 \\
\hline $\begin{array}{l}\text { Fichtner et al. } \\
\text { (2004), ref. } 20\end{array}$ & 32 & Ventral & $>60$ & & 13 & 13 \\
\hline Present study & 19 & Ventral & 19 & 42 & 37 & 0 \\
\hline
\end{tabular}


Only 2 series report complications with enough detail to compare directly to our data. Complications after anastomotic urethroplasty were published from University of California-San Francisco (UCSF) (2) (Table-6) and detailed complications of 84 fasciocutaneous urethroplasty were published from the Institute of Urology in London (Table-7) (11). The UCSF series showed a comparable degree of nuisance complications but they differed in their makeup (Table-6) and showed a much lower rate of ED than seen in our series. This may be due to incomplete questioning of the patients, as this rate climbed sharply when this group later specifically queried the patients about erectile dysfunction (8). The London series also showed some of the same complications we have seen (such as post void dribbling), while in their series urinary tract infection (UTI) and urethral diverticula were seen there, but not in our data. In general, we report a significantly higher overall rate of complications than that reported elsewhere, even when minor complications are not counted (Tables-8, 9, 10, 11).

Minimal urinary leakage after voiding was common and may be an expected result of decreased urethral elasticity as a result of stricture disease or its treatments. It is so common that likely all patients should be warned before urethroplasty surgery, as surgery seems to cause or unmask it clinically in a certain percentage.

\section{Complications of Positioning}

We had positional complications in only one patient $(2 \%)$ who had temporary hand numbness. None of our patients reported thigh numbness. Previous reports have generally shown a higher percentage of positional complications than seen in our series, ranging between $10-20 \%(12,13)$. We attribute

Table 11 - Reported complication post fasciocutaneous urethroplasty.

\begin{tabular}{|c|c|c|c|c|c|c|c|}
\hline Reference & $\mathbf{N}$ & $\begin{array}{c}\text { Type of } \\
\text { Urethroplasty }\end{array}$ & $\begin{array}{c}\text { Mean } \\
\text { Follow-up } \\
\text { (months) }\end{array}$ & $\begin{array}{c}\text { Early } \\
\text { Complica- } \\
\text { tions }(\%)\end{array}$ & $\begin{array}{c}\text { Late } \\
\text { Complica- } \\
\text { tions }(\%)\end{array}$ & $\begin{array}{c}\text { Recurrence } \\
\text { Rate }(\%)\end{array}$ & $\begin{array}{c}\text { All Com- } \\
\text { plications } \\
\quad(\%)\end{array}$ \\
\hline $\begin{array}{l}\text { Andrich et al. } \\
\text { (2003), ref. } 11\end{array}$ & 84 & fasciocutaneous & 120 & & & 31 & 33 \\
\hline $\begin{array}{l}\text { Andrich et al. } \\
\text { (2003), ref. } 11\end{array}$ & 84 & fasciocutaneous & 60 & & & 21 & \\
\hline $\begin{array}{l}\text { McAninch \& Morey } \\
\text { (1998), ref. } 21\end{array}$ & 54 & fasciocutaneous & 41 & & & 13 & \\
\hline $\begin{array}{l}\text { El-Kasaby et al. } \\
\text { (1996), ref. } 22\end{array}$ & 29 & $\begin{array}{l}\text { fasciocutaneous (for } \\
\text { stricture and complex } \\
\text { hypospadias) }\end{array}$ & 19 & & & & 17 \\
\hline $\begin{array}{l}\text { Morey et al. } \\
(2000) \text {, ref. } 23\end{array}$ & 15 & $\begin{array}{l}\text { fasciocutaneous } \\
\text { (Q flap) }\end{array}$ & 43 (in 13) & & & 13 & 33 \\
\hline $\begin{array}{l}\text { Lindell et al. } \\
\text { (1993), ref. } 14\end{array}$ & 18 & Quartey & 48 & & & 6 & 67 \\
\hline Present study & 10 & fasciocutaneous & 26 & 60 & 60 & 40 & 60 \\
\hline
\end{tabular}


our low rates to surgery times that were kept as short as possible and the evolution of meticulous positioning protocols over time using multiple aids including a gel-padded bean bag, sequential compression devices, compression stockings, and arm padding, all which have been previously described (2).

\section{Success Rates}

Success rates varied by urethroplasty type (Tables-2, 3, 4, 5, 12). Ventral buccal mucosal onlay had the highest success rate $(100 \%)_{2}$ even when used against reasonably long strictures (mean stricture length was $3.4 \mathrm{~cm}$ ). Posterior anastomotic urethroplasties also had a $100 \%$ success rate over the observation period. The next most successful was anterior anastomotic urethroplasty (92\%) for mean stricture length of $1.6 \mathrm{~cm}$. Fasciocutaneous urethroplasty had the lowest success rate $(60 \%)$ and was of course used only against the longest strictures (mean $5.7 \mathrm{~cm})$.

\section{Limitations}

This study has 2 limitations. The first is that some groups have small numbers ( 9 patients in the posterior anastomotic group) but overall we believe it gives a good overview of the expected sequellae of a wide range of urethroplasty surgery operations. The second is that it is retrospective in nature, and while we understand the theoretical advantage of prospective versus retrospective studies, it is not certain that a prospective study would give any more accurate results than we have obtained here.

\section{CONCLUSION}

Meticulous follow up of post urethroplasty surgery patients shows a high percentage of early and late complications, although many of these are minor in scope. Serious complications (3\% early and $18 \%$ late) appear similar to those reported elsewhere, but minor bothersome complications appear to occur in much higher numbers than previously published (39\% early and $40 \%$ late). All early complications were resolved and most (97\%) were minor, but less than half of the late complications were resolved and a lower percentage (82\%) was minor. A full reckoning of the
Table 12 - Urethral stricture recurrence in urethroplasty patients and its management.

Success Rate and Postoperative Recurrence N (\%) Management

Anterior Anastomotic Urethroplasty

No recurrence

Recurrence treated with single DVIU

Recurrence treated with two DVIU

Buccal Mucosal Onlay Urethroplasty

No recurrence

Fasciocutaneous Urethroplasty

No recurrence

Recurrence awaiting treatment

Recurrence treated with two DVIU

1 (10)

Recurrence treated with three DVIU

Recurrence treated with perineal urethrostomy

Posterior Anastomotic Urethroplasty

No recurrence

$D V I U=$ direct visual internal urethrotomy

impact of urethroplasty surgery, including these minor complaints that nonetheless bother the patient will help the patient and surgeon understand the full implications of planned urethroplasty surgery.

\section{REFERENCES}

1. Flynn BJ, Delvecchio FC, Webster GD: Perineal repair of pelvic fracture urethral distraction defects: experience in 120 patients during the last 10 years. J Urol. 2003; 170: 1877-80.

2. Santucci RA, Mario LA, McAninch JW: Anastomotic urethroplasty for bulbar urethral stricture: analysis of 168 patients. J Urol. 2002; 167: 1715-9.

3. Elliott SP, Metro MJ, McAninch JW: Long-term followup of the ventrally placed buccal mucosa onlay graft in bulbar urethral reconstruction. J Urol. 2003; 169: 1754-7.

4. Pansadoro V, Emiliozzi P, Gaffi M, Scarpone P, DePaula F, Pizzo M: Buccal mucosa urethroplasty in the treatment of bulbar urethral strictures. Urology. 2003; 61: 1008-10. 
5. Andrich DE, Leach CJ, Mundy AR: The Barbagli procedure gives the best results for patch urethroplasty of the bulbar urethra. BJU Int. 2001; 88: 385-9.

6. Heyns CF, Steenkamp JW, De Kock ML, Whitaker P: Treatment of male urethral strictures: is repeated dilation or internal urethrotomy useful? J Urol. 1998; 160: 356-8.

7. Pansadoro V, Emiliozzi P: Internal urethrotomy in the management of anterior urethral strictures: long-term followup. J Urol. 1996; 156: 73-5.

8. Coursey JW, Morey AF, McAninch JW, Summerton DJ, Secrest C, White P, et al.: Erectile function after anterior urethroplasty. J Urol. 2001; 166: 2273-6.

9. Andrich DE, Mundy AR: Surgery for urethral stricture disease. Contemp Urol. 2001; 13: 32-44.

10. Andrich DE, Greenwell TJ, Mundy AR: The problems of penile urethroplasty with particular reference to 2stage reconstructions. J Urol. 2003; 170: 87-9.

11. Andrich DE, Dunglison N, Greenwell TJ, Mundy AR: The long-term results of urethroplasty. J Urol. 2003; 170: 90-2.

12. Anema JG, Morey AF, McAninch JW, Mario LA, Wessells H: Complications related to the high lithotomy position during urethral reconstruction. J Urol. 2000; 164: 360-3.

13. Angermeier KW, Jordan GH: Complications of the exaggerated lithotomy position: a review of 177 cases. J Urol. 1994; 151: 866-8.

14. Lindell O, Borkowski J, Noll F, Schreiter F: Urethral stricture repair: results in 179 patients. Scand J Urol Nephrol. 1993; 27: 241-5.
15. Schlossberg SM: Anastomotic Urethral Reconstruction. American Urologic Association. Postgraduate Course. 2000.

16. Mundy AR: Urethroplasty for posterior urethral strictures. Br J Urol. 1996; 78: 243-7.

17. Morey AF, McAninch JW: Reconstruction of posterior urethral disruption injuries: outcome analysis in 82 patients. J Urol. 1997; 157: 506-10.

18. Kellner DS, Fracchia JA, Armenakas NA: Ventral onlay buccal mucosal grafts for anterior urethral strictures: long-term followup. J Urol. 2004; 171: 726-9.

19. Kane CJ, Tarman GJ, Summerton DJ, Buchmann CE, Ward JF, O'Reilly KJ, et al.: Multi-institutional experience with buccal mucosa onlay urethroplasty for bulbar urethral reconstruction. J Urol. 2002; 167: 13147.

20. Fichtner J, Filipas D, Fisch M, Hohenfellner R, Thuroff JW: Long-term outcome of ventral buccal mucosa onlay graft urethroplasty for urethral stricture repair. Urology. 2004; 64: 648-50.

21. McAninch JW, Morey AF: Penile circular fasciocutaneous skin flap in 1-stage reconstruction of complex anterior urethral strictures. J Urol. 1998; 159: 1209-13.

22. el-Kasaby AW, Alla MF, Noweir A, Mourad S, Youssef AH: One-stage anterior urethroplasty. J Urol. 1996; 156: 975-8.

23. Morey AF, Tran LK, Zinman LM: Q-flap reconstruction of panurethral strictures. BJU Int. 2000; 86: 103942.

\section{Correspondence address:}

Dr. Richard A. Santucci

Detroit Receiving Hospital

4160 John R. Suite 1017

Detroit, Michigan, 48201, USA

Fax: + 1313 745-0464

E-mail: rsantucc@med.wayne.edu 


\section{EDITORIAL COMMENT}

This is an interesting retrospective analysis of extensive early and late complications after urethroplasties performed by the same experienced surgeon (RAS). Although the manuscript tried to add new information to the literature of complications after urethral surgery, several concerns and issues have to be considered.

Unfortunately, the 60 consecutive patients enrolled in the analysis cannot be considered a homogeneous group. The authors included patients with anterior and posterior urethral strictures, with different etiologies, with a wide range in length, and, furthermore, they used different techniques. No surgery was performed for repairing strictures in patients with hypospadias failure and no dorsal onlay buccal mucosa grafts were done in this series. Ruling out these 2 conditions could represent a significant limitation to reporting complications. I suggest that the main criteria for studying early and late complications are a homogeneous group of patients chosen according to selective criteria.

Other points of interest include the relatively small sample size, which the authors correctly mention in the discussion, and the short-term follow-up. The mean follow-up was reported to be 29 months with a range between 10-53 months. Long-term follow-up (5 years) is important in estimating the rates of recurrence (late complications). The longer and more you follow patients after surgery, the less you will be satisfied with your results, although these results are considered quite good after 2 years.

To the reader, the method of studying the complications appears vague, excessively subjective and imprecise. The authors investigated only the local perineal and urethral complications, forgetting the oral complications after buccal mucosa graft (BMG), which they performed on 19 patients. BMG has emerged as safe and reliable material for urethral reconstruction but the morbidity associated with harvesting BMG is still an open problem (1). Recently, Barbagli investigated the early and late complications after BMG harvest from a cheek in a homogeneous series of 90 patients (2). He used a closed questionnaire administered by telephone by a neutral person not on the staff of the hospital, which included 6 questions designed to investigate the early (first 10 postoperative days) complications and 14 questions to investigate the late ones. The early complications were bleeding (4\%), pain $(21 \%)$ and swelling (42\%). The main late complication was perioral numbness for 1 month (34\%), while no significant discomfort due to the scar, difficulty with mouth opening, difficulty in smiling or changes in the face physiognomy were reported.

In conclusion, the choices that are available to reconstruct the urethra are continuously developing and focused attention is required to old and new concepts. The successful management of urethral strictures, which in other words means an increase of long-term positive outcome and a low rate of complications, is demanding for reconstructive surgeons and it depends on different factors, including surgical skill as well as the right criteria for patient and surgery selection. Certainly, the use of a fasciocutaneous flap or graft should not compromise penile length, should not cause chordee and should not affect penile appearance. Oral morbidity should be considered after BMG in order to avoid permanent late sequel in mouth function. Finally, sexual function can be placed at risk by any urethral surgery and any dissection, especially for posterior urethral reconstruction, should avoid interference with the neurovascular bundles to the penis.

\section{REFERENCES}

1. Armenakas NA: Long-term outcome of ventral buccal mucosal grafts for anterior urethral strictures. AUANews. 2004; 9(3): 17.

2. Barbagli G, Palminteri E, Guazzoni G, Turini D, Lazzeri M: The morbidity of buccal mucosa graft harvest from cheek in 90 adult patients J. Urol. 2005; 173 (suppl.), 33: Abst. 122.

\author{
Dr. Massimo Lazzeri \\ Department of Urology \\ Casa di Cura Santa Chiara Firenze \\ Florence, Italy
}




\section{EDITORIAL COMMENT}

\section{Limiting Complications from Urethroplasty}

Complications from urethral reconstruction may occur either in relation to the local, technical nature of the repair (re-stenosis, dribbling, spraying, scrotal numbness, skin necrosis) or to high lithotomy positioning (lower extremity compartment syndrome, neuropraxia, rhabdomyolysis). There is no question that expertise in urethral reconstruction reduces the incidence of both conditions and that longer strictures are more problematic than short.

The most important thing we have done to reduce position-related complications has been to avoid prolonged leg elevation at all costs. Our comprehensive literature review on this subject published in 2000 (reference 12 in the article) indicated clearly that high lithotomy-related complications occur predominantly during procedures lasting 5 hours or longer. We have since adopted a "5-hour rule" for high lithotomy positioning that has completely eliminated this problem in our practice. For complex cases, we proceed in a distal-to-proximal manner with the patient supine, elevating the legs only when necessary to reach the perineum. In panurethral reconstructions, we often re-prep and re-drape at the halfway point after repositioning.
Grafts are better than penile skin flaps for bulbar urethral reconstructions because they are equally efficacious and much more efficient technically. By harvesting the buccal grafts at the beginning of the case with the patient in the supine position, the legs may be elevated, again, only when exposing the perineum.

To reduce stricture recurrence from anastomotic and posterior urethroplasty, the key is to adequately excise all periurethral fibrotic tissue. I like to use multiple traction sutures in the scar to "lift" it out (as taught by Dr. McAninch) in a way that a $28 \mathrm{~F}$ bougie passes easily. Tension-free anastomosis is accomplished by extensively mobilizing the distal urethral segment from its scrotal attachments, especially on its ventral aspect where no blood supply exists.

To reduce stricture recurrence from graft and flap procedures, the question that must be asked is, "What am I patching on to?" I suspect many failures occur due to an inadequate urethral plate and often try to "salvage" a deficient plate by mobilizing, excising, and/or grafting until the plate is approximately $1 \mathrm{~cm}$ wide.

Dr. Allen F. Morey

Chief of Urology, Brooke Army Medical Center

Urology Service, MCHE-SDU

Fort Sam Houston, Texas, USA 